\title{
Correction to: Processing of raspberries to dried fruit foam: impact on major odorants
}

\author{
Silvia Lang ${ }^{1} \cdot$ Mine Ozcelik $^{2}$ - Ulrich Kulozik ${ }^{2} \cdot$ Martin Steinhaus $^{1}$
}

Published online: 18 June 2021

(c) The Author(s) 2021

\section{Correction to: \\ European Food Research and Technology (2020) 246:2537-2548 https://doi.org/10.1007/s00217-020-03595-9}

The article "Processing of raspberries to dried fruit foam: impact on major odorants", written by Silvia Lang, Mine Ozcelik, Ulrich Kulozik and Martin Steinhaus, was originally published Online First without Open Access. After publication in volume 246, issue 12, page 2537-2548 the author decided to opt for Open Choice and to make the article an Open Access publication. Therefore, the copyright of the article has been changed to $($ The Author(s) 2020 and the article is forthwith distributed under the terms of the Creative Commons Attribution 4.0 International License, which permits use, sharing, adaptation, distribution and reproduction in any medium or format, as long as you give appropriate credit to the original author(s) and the source, provide a link to the Creative Commons licence, and indicate if changes were made. The images or other third party material in this article are included in the article's Creative Commons licence, unless indicated otherwise in a credit line to the material. If material is not included in the article's Creative Commons licence and your intended use is not permitted by statutory regulation or exceeds the permitted use, you will need to obtain permission directly from the copyright holder. To view a copy of this licence, visit http:// creativecommons.org/licenses/by/4.0.

The original article can be found online at https://doi.org/10.1007/ s00217-020-03595-9.

\section{Martin Steinhaus}

martin.steinhaus@tum.de

1 Leibniz-Institute for Food Systems Biology at the Technical University of Munich, Leibniz-LSB @ TUM,

Lise-Meitner-Strase 34, 85354 Freising, Germany

2 Chair of Food and Bioprocess Engineering, Technical University of Munich, Weihenstephaner Berg 1, 85354 Freising, Germany
Open access funding enabled and organized by Projekt DEAL.

Original article has been corrected.

Publisher's Note Springer Nature remains neutral with regard to jurisdictional claims in published maps and institutional affiliations. 